\title{
Association between SNP Marker of Uncoupling Protein 3 Gene and Meat Yield and Marbling Score Traits in Korean Cattle
}

\author{
Eui-Ryong Chung*, Sung-Chul Shin, and Jae-Pil Heo \\ Division of Animal Science and Resources, College of Life Science and Natural Resources, \\ Sangji University, Wonju 220-702, Korea
}

\begin{abstract}
It is well established that uncoupling protein 3 (UCP3) is expressed largely in skeletal muscle, white adipose tissue and brown adipose tissue and has been suggested to play important roles in regulating energy expenditure, body weight, thermoregulation as well as fatty acid metabolism and obesity. Therefore, the UCP3 gene was selected as a candidate gene for carcass and meat quality traits in Korean cattle. The objective of this study was to identify single nucleotide polymorphisms (SNPs) in the UCP3 gene and to evaluate the association of UCP3 SNP markers with carcass and meat quality traits in Korean cattle. The five exons in the UCP3 gene were sequenced, and ten SNPs were identified. The PCR-SSCP method was then developed to genotype the individuals examined. The g.3076A $>\mathrm{G}$ genotype was significantly associated with marbling score (MS) of Korean cattle. Animals with the AA genotype had a higher MS than those with the AG and GG genotypes. No significant associations of the SNP g.3076A $>$ G were observed for any traits. In conclusion, although SNP g.3076A $>$ G, which showed an association with MS, does not cause amino acid changes, this SNP may be used as a DNA marker to select animals that have higher intramuscular fat content.
\end{abstract}

Key words: uncoupling protein 3 gene, single nucleotide polymorphisms marker, meat quality traits, marbling score, Korean cattle

\section{Introduction}

Meat quality is of great importance to the beef industry where the consumer is willing to pay more for high quality products (Gill et al., 2010). Intramuscular fat, so called marbling, is an important factor for evaluation of beef quality, and increasing intramuscular fat is the major target in beef industries in Korea. Deposition of intramuscular fat in beef cattle contributes to meat quality variables, including taste, juiciness, flavor, and tenderness. Therefore, it would be beneficial to producers if a method for ranking animals for economic traits such as marbling and tenderness were developed. However, meat quality traits can usually only be measured post-slaughter, so that making progress using direct measurements is difficult (Gill et al., 2010). Also, the degree of marbling is hard to predict because it is not strongly correlated with subcutaneous fat, so fattening cattle to improve marbling and then

\footnotetext{
*Corresponding author: Eui-Ryong Chung, Division of Animal Science and Resources, College of Life Science and Natural Resources, Sangji University, Wonju 220-702, Korea. Tel: 8233-730-0534, Fax: 82-33-744-6118, E-mail: erchung@sangji. ac.kr
}

choosing to turn off animals on the basis of the fatness under the skin is not an accurate way to get high marbling scores (Barendse et al., 2009). The accumulation of intramuscular fat is largely influenced by the genetic background of cattle, as well as their age and nutrition (Wang et al., 2009). Recent research has suggested that DNA markers are related to marbling deposition. Thus, it is important to identify candidate genes that can be used as early biomarkers for the prediction of marbling development in cattle. Biomarkers found in various candidate genes linked to economically important traits have been identified and incorporated into commercially available DNA marker tests for meat quality in beef cattle (Gill et al., 2010; Van Eenennaam et al., 2007). Candidate genes are selected based on their potential effects on carcass and meat traits. The possible effects of these genes on carcass and meat traits can be judged based on the known involvement of the gene product in cellular or metabolic processes such as energy homeostasis (Haegeman et al., 2003).

Uncoupling protein 3 (UCP3) is a member of the mitochondrial anion carrier family primarily expressed in skeletal muscle and brown adipose tissue (Boss et al., 
1997; Matsuda et al., 1997). Due to its high homology to UCP1, which plays an important role in adaptive thermogenesis, a primary function of UCP3 was thought to be control of thermogenesis (Katsumata et al., 2004). The genes that codes for novel uncoupling protein play an important role in energy metabolism, and it has been reported that UCP gene was partially involved in the obesity (Fleury et al., 1997; Zhao et al., 2002). In addition, UCP gene also can be regulated by leptin, the production of the obesity gene, which plays an important role in the energy intake and expenditure (Zhao et al., 2005). Therefore, based on the physiological and biochemical roles of UCP3 in fat and energy metabolisms, the gene encoding UCP3 was chosen as a candidate gene for association tests with carcass and meat quality traits in beef cattle. The objective of this study was to identify single nucleotide polymorphisms (SNPs) of the UCP3 gene and to evaluate associations between SNP marker of the UCP3 gene and carcass and meat quality traits in Korean cattle.

\section{Materials and Methods}

\section{Animals and carcass data}

A total of 309 Hanwoo steers produced from 49 sires used in progeny testing program of National Livestock Research Institute (NLRI) of Korea were used in this study. All steers of the national progeny-testing population were fed under the tightly controlled conditions of the feeding program. Meat samples were collected from $13^{\text {th }}$ thoracic rib to the first lumbar vertebrae of the steers within $24 \mathrm{~h}$ of slaughter and evaluated by mechanical and physical methods according to the Animal Product Grading System of Korea. The carcass data analyzed were live weight (LW), carcass weight $(\mathrm{CW})$, dressing percentage (DP), backfat thickness (BF), M. Longissimus dorsi area (LDA) and marbling score (MS). BF and LDA were measured at the $12^{\text {th }}$ - and $13^{\text {th }}$ - rib interface. MS for quality grade was evaluated on a cross section of the longissimus muscle at the $12^{\text {th }}$ - to $13^{\text {th }}$-rib interface by official graders
Table 1. Mean, standard deviation (SD) and extreme values of phenotypic values measured on each trait in Korean cattle

\begin{tabular}{lccccc}
\hline \multicolumn{1}{c}{ Traits } & No. & Mean & SD & Minimum & Maximum \\
\hline $\mathrm{LW} / \mathrm{kg}$ & 309 & 538.22 & 51.564 & 390 & 690 \\
$\mathrm{CW} / \mathrm{kg}$ & 309 & 307.29 & 32.558 & 212 & 401 \\
$\mathrm{DP} / \%$ & 309 & 57.1 & 1.6 & 52.6 & 62.4 \\
$\mathrm{BF} / \mathrm{cm}$ & 309 & 0.7 & 0.3 & 0.2 & 1.8 \\
$\mathrm{EMA} / \mathrm{cm}^{2}$ & 309 & 75.466 & 8.195 & 54 & 97 \\
$\mathrm{MS} 1 / 1-7$ & 309 & 2.35 & 1.43 & 1 & 7 \\
$\mathrm{MS} 2 / 1-3$ & 309 & 2.25 & 0.78 & 1 & 3 \\
$\mathrm{CW}-\mathrm{EBV}$ & 309 & 1.568 & 10.214 & -24.119 & 33.076 \\
EMA-EBV & 309 & 0.503 & 3.416 & -8.548 & 8.889 \\
MS-EBV & 309 & 0.062 & 0.598 & -1.062 & 2.917 \\
$\mathrm{BF}-\mathrm{EBV}$ & 309 & 0.026 & 0.412 & -0.706 & 2.226 \\
\hline
\end{tabular}

LW, live weight; CW, carcass weight; DP, dressing percentage; BF, backfat thickness; EMA, M. Longissimus dorsi area; MS, marbling score ; EBV, estimated breeding value

according to the Korean Beef Marbling Standard. MS is scored on a scale from 1 to 7 with 7 being associated with the best marbling. The mean and standard deviations for traits analyzed in this study are presented in Table 1. For each animal, genomic DNA was extracted from whole blood by using a $\mathrm{NaCl}$ precipitation protocol (Miller et al., 1988). The DNA sample was suspended in TE buffer (10 mM Tris-HCl, pH 7.4; 1 mM EDTA) and stored at $-20^{\circ} \mathrm{C}$ until analysis.

\section{Sequence analysis and SNP discovery}

Three pairs of primers for amplification and sequencing analysis were designed based on the genomic DNA sequence of the bovine UCP3 gene from nucleotides 8203463 of GenBank accession no. AF127030 that included five exon regions (exons 2-6) to amplify 461-1293 bp fragments using Primer 3 program (http://frodo.wi.mit. edu/). The sequences of primers are shown in Table 2. To determine SNP identification, pooled DNA samples from the sixty unrelated animals were amplified by PCR using the each primer pair. The PCR amplification was performed in a DNA thermal cycler (Perkin Elmer Cetus,

Table 2. Primer pairs used for sequencing and SNP discovery of the UCP3 gene in Korean cattle

\begin{tabular}{|c|c|c|c|c|}
\hline Primer sequences $\left(5^{\prime}-3^{\prime}\right)$ & Location & $\begin{array}{l}\text { Fragment size } \\
\text { (bp) }\end{array}$ & $\begin{array}{l}\text { Annealing temp. } \\
\qquad\left({ }^{\circ} \mathrm{C}\right)\end{array}$ & $\begin{array}{c}\text { GenBank } \\
\text { accession no. }\end{array}$ \\
\hline $\begin{array}{l}\text { F-GCCCGGAGTGCCCAGTA } \\
\text { R-CGCCAAAATCCGGGTAATG }\end{array}$ & $820-1281$ & 461 & 54 & \multirow{3}{*}{ AF 127030} \\
\hline $\begin{array}{l}\text { F-ACGGGGGCCATGGCAGTGAC } \\
\text { R-TCCTCGTGATGTTGGGCAGAAT }\end{array}$ & $1291-2583$ & 1293 & 60 & \\
\hline $\begin{array}{l}\text { F-TCTGCCCAACATCACGAGGAAT } \\
\text { R-CCTGGGGGCGAGTTCATA }\end{array}$ & $2564-3463$ & 900 & 58 & \\
\hline
\end{tabular}


USA). The PCR reaction was performed in a $20 \mu \mathrm{L}$ reaction mixture containing $10 \mathrm{pmol}$ of each primer, $1.5 \mathrm{mM}$ $\mathrm{MgCl}_{2}, 200 \mu \mathrm{M}$ of each dNTP and 1 unit of Taq DNA polymerase, $10 \times$ reaction buffer and $50 \mathrm{ng}$ of genomic DNA as template. The PCR conditions were $94^{\circ} \mathrm{C}$ for $5 \mathrm{~min}$, followed by 35 cycles of $94^{\circ} \mathrm{C}$ for $1 \mathrm{~min}, 54-60^{\circ} \mathrm{C}$ and for $1 \mathrm{~min}$ and $72^{\circ} \mathrm{C}$ for $1 \mathrm{~min}$, with a final extension at $72^{\circ} \mathrm{C}$ for $5 \mathrm{~min}$. The product of the PCR was verified by $2.5 \%$ agarose gel electrophoresis and purified with Wizard Prep PCR purification kit (SolGent, Korea). The purified DNA fragments were directly sequenced in both directions using BigDye ${ }^{\mathrm{TM}}$ Terminator V3.1 Cycle Sequencing kit in an ABI 3130 genetic analyzer (Applied Biosystems, USA). Sequencer Software V5.1 (Applied Biosystems) was used to assemble the sequences and to identify polymorphisms.

\section{SNP genotyping using PCR-SSCP}

Genotyping of the SNP located at position g.3076A $>\mathrm{G}$ (numbering according to GenBank database accession no. AF127030) within intron $\mathrm{V}$ region of the UCP3 gene was performed by a PCR-single strand conformation polymorphism (SSCP) method, because no restriction site exists for this SNP. The PCR amplification was carried out using forward (5'-ACTGCAAGAGATTTGGAAAA-3') and reverse (5'-TCCGTCAAATCTGACTCTTT-3') primers designed for amplification of $230 \mathrm{bp}$ fragment including SNP g.3076A $>\mathrm{G}$ site. The $20 \mu \mathrm{L}$ reaction mixture contained $50 \mathrm{ng}$ of genomic DNA, $0.1 \mu \mathrm{M}$ of each primer, $2 \mu \mathrm{L} 10 \times$ PCR buffer, $1.5 \mathrm{mM} \mathrm{MgCl} 2,250 \mu \mathrm{M}$ of each dNTP and 1 unit Taq polymerase. Amplification conditions were $94^{\circ} \mathrm{C}$ for $5 \mathrm{~min}$ followed by 35 cycles of $94^{\circ} \mathrm{C}$ for $30 \mathrm{~s}, 55^{\circ} \mathrm{C}$ for $30 \mathrm{~s}$ and $72^{\circ} \mathrm{C}$ for $30 \mathrm{~s}$, with a final extension at $72^{\circ} \mathrm{C}$ for $5 \mathrm{~min}$ in a DNA thermal cycler (Perkin Elmer Cetus). After PCR amplification, $1 \mu \mathrm{L}$ of PCR product was mixed with $4 \mu \mathrm{L}$ of gel loading solution containing $95 \%$ formamide, $20 \mathrm{mM}$ EDTA, $0.05 \%$ bromophenol blue and $0.05 \%$ xylene cyanol. The mixture was then denaturated at $95^{\circ} \mathrm{C}$ for $5 \mathrm{~min}$, cooled on ice for $10 \mathrm{~min}$ and loaded on nondenaturing $12 \%$ polyacrylamide gels (49:1 acrylamide to bis-acrylamide). Electrophoresis was performed in $1 \times$ TBE buffer at $250 \mathrm{~V}$ for 4 $6 \mathrm{~h}$ at room temperature. After electrophoresis, the DNA fragments in the gel were detected by silver staining. To define each genotype according to band patterns, the PCR products of different SSCP patterns corresponding to each genotype were sequenced and analyzed for nucleotide changes.

\section{Statistical analysis}

Allele and genotype frequencies were calculated by simple allele counting method. Hardy-Weinberg equilibrium (HWE) in examined population was tested by comparing expected and observed genotype frequencies using a Chi-square test. The PROC GLM procedure of SAS (Release 9.1, SAS, Inst. Inc., Cary NC, 2008) was used to test the association between SNP marker genotypes of the UCP3 gene and carcass and meat quality traits. The linear model used was as follows:

$$
Y_{i j k m}=\mu+S_{i}+Y S_{j}+S P_{K}+A_{l}+G_{m}+e_{i j k l m}
$$

Where $Y_{i j k l m}$ is the observation of the carcass traits, $\mu$ is the overall mean for each trait, $S_{i}$ is the effect of sire, $Y S_{i}$ is the effect of $i_{t h}$ year and season of calving, $S P_{k}$ is the effect of slaughter place, $A_{l}$ is the effect of age at slaughter (covariate), $G_{m}$ is the fixed effect of SNP genotype and $e_{i j k l m}$ is the random residual effect. Significance differences among mean values of different genotypes were calculated using Duncan's multiple range test, and determined to be statistically significant at $p<0.05$.

The additive and dominance effects were also estimated using REG procedure of SAS version 9.2, where the additive effect was denoted as $-1,0$ and 1 for AA, AG and GG, respectively, and the dominance effect was denoted as $1,-2$ and 1 for AA, AG and GG, respectively.

\section{Results}

\section{SNP identification in the Hanwoo UCP3 gene}

For SNP detection of the UCP3 gene in Hanwoo, we sequenced five regions from exon II to exon VI of the UCP3 gene. Ten nucleotide substitutions were identified, which were one (g.1099G $>$ A) in intron III, six (g.1594A $>$ C, g.1638G $>$ A, g.1794Del(A), g.1796A $>$ G, g.1801Del (T) and g.2457T $>$ C) in intron IV, and three (g.2689C $>$ T, g.2966A $>$ C and g.3076A $>$ G ) in intron V (Fig. 1).

\section{SNP genotyping by using PCR-SSCP}

Genotyping of the SNP located at position g.3076A $>$ G within the intron $\mathrm{V}$ region of the UCP3 gene was performed by a PCR-SSCP method (Fig. 2). The allele and genotype frequencies of the UCP3 gene estimated for the Hanwoo population are shown in Table 3. In g.3076A $>$ G SNP, the frequency of allele A (53.1\%) was higher than that of allele $\mathrm{G}(46.9 \%)$. In the genotype frequencies, the heterozygous genotype AG showed higher frequency (53.1\%) compared to either homozygous genotype AA or $\mathrm{GG}$, whereas the two homozygous genotypes AA and GG 


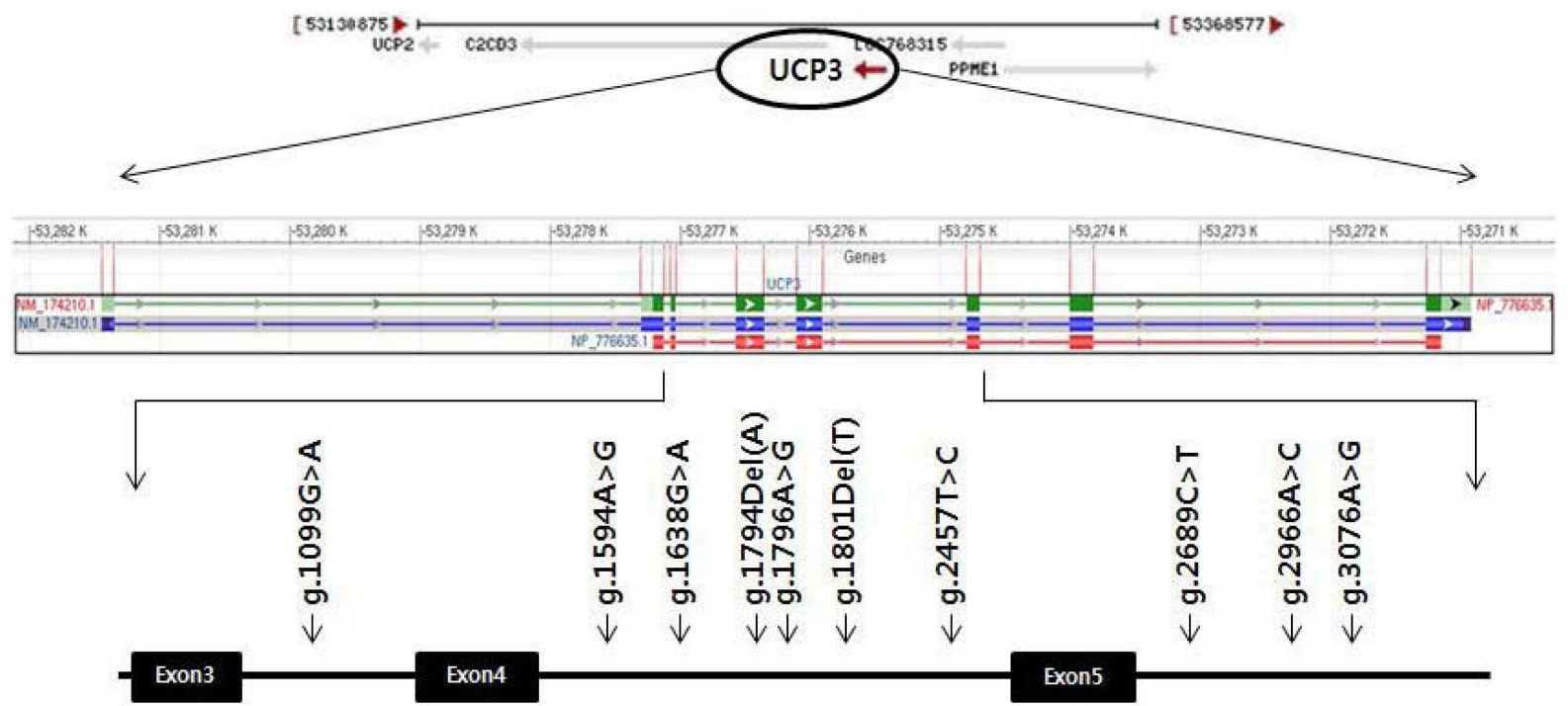

Fig. 1. Map position of SNPs identified in the UCP3 gene of Korean cattle. The SNPs were detected in the introns 3, 4, and 5, respectively.

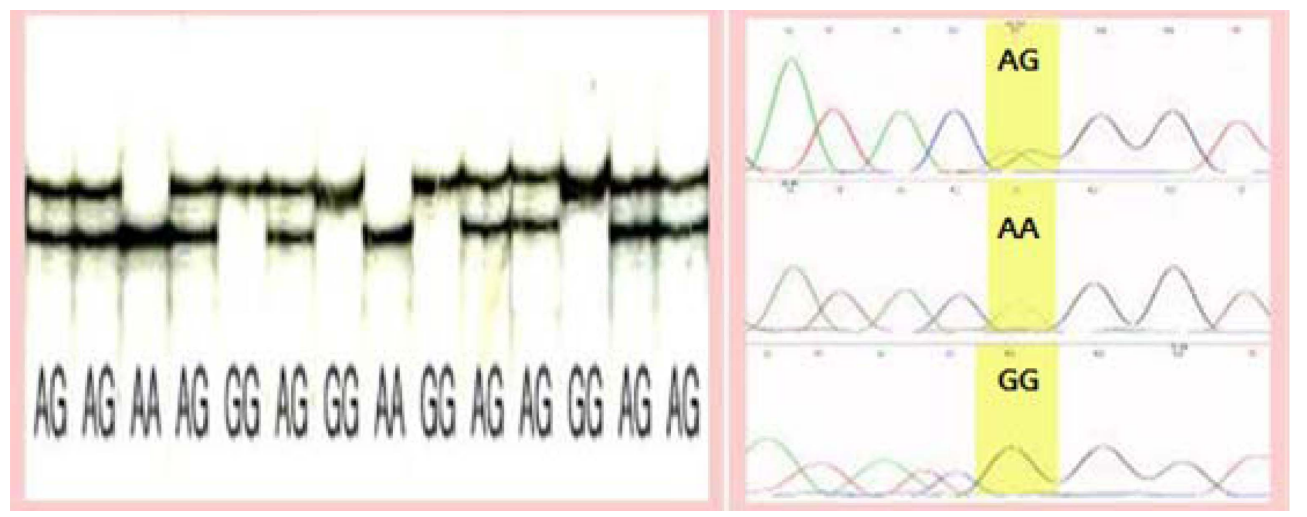

Fig. 2. PCR-SSCP analysis and sequence chromatograms for the detection of the gene specific SNP of the UCP3 gene in Korean cattle. SNP with the $A>G$ substitution were detected at position 3076 (g.3076A $>$ G) within intron 5 region of the UCP3 gene.

Table 3. Genotype and allele frequencies for g.3076A>G marker of the UCP3 gene in Korean cattle

\begin{tabular}{|c|c|c|c|c|c|c|c|c|c|c|}
\hline \multirow{2}{*}{ SNP marker } & \multirow{2}{*}{$\begin{array}{c}\text { No. of } \\
\text { animals }\end{array}$} & \multicolumn{5}{|c|}{ Frequencies (\%) } & \multirow{2}{*}{$\mathrm{He}^{1)}$} & \multirow{2}{*}{$\mathrm{PIC}^{2)}$} & \multicolumn{2}{|c|}{ HWE $^{3)}$} \\
\hline & & \multicolumn{3}{|c|}{ Genotype } & \multicolumn{2}{|c|}{ Allele } & & & $\operatorname{ccc}^{2}$ & $p$-value \\
\hline \multirow{2}{*}{ UCP3 g.3076A>G } & \multirow{2}{*}{309} & $\mathrm{AA}$ & $\mathrm{AG}$ & GG & $\mathrm{A}$ & $\mathrm{G}$ & \multirow{2}{*}{0.606} & \multirow{2}{*}{0.537} & \multirow{2}{*}{1.329} & \multirow{2}{*}{0.514} \\
\hline & & 26.5 & 53.1 & 20.4 & 53.1 & 46.9 & & & & \\
\hline
\end{tabular}

${ }^{1)}$ heterozygosity

${ }^{2)}$ polymorphic information content

${ }^{3)}$ Hardy-Weinberg equilibrium

had similar frequencies (26.5 and 20.4\%, respectively). The observed genotype distributions were in good agreement with those expected according to the Hardy-Weinberg equilibrium in this population.

\section{Association of gene-specific SNP marker with car- cass traits}

Results of the SNP markers association analysis are pre- sented in Table 4. The SNP marker of g.3076A $>$ G was significantly associated $(p<0.0209)$ with the MS. Animals with the AA (2.538 \pm 0.194$)$ genotype had higher MS than those with the AG (1.910 \pm 0.137$)$ and GG (1.866 \pm 0.222$)$ genotypes. This SNP genotype also showed a significant additive genetic effect for the MS $(p<0.05)$. No significant associations, however, was detected between any of the SNP genotype and other carcass traits measured in this study. 
Table 4. Associations of UCP3 SNP g.3076A $>$ G variation with carcass and meat quality traits in Korea cattle

\begin{tabular}{|c|c|c|c|c|c|c|}
\hline \multirow{2}{*}{ Traits } & \multicolumn{3}{|c|}{ "SNP genotype (mean \pm SE) } & \multirow{2}{*}{$p$-value } & \multicolumn{2}{|c|}{ Genetic Effects (mean \pm SE) } \\
\hline & $\mathrm{AA}(\mathrm{n}=82)$ & $\mathrm{AG}(\mathrm{n}=164)$ & GG $(n=63)$ & & Additive & Dominance \\
\hline $\mathrm{LW} / \mathrm{kg}$ & $539.487 \pm 8.221$ & $548.205 \pm 5.813$ & $543.000 \pm 9.373$ & 0.6719 & $-3.512 \pm 12.467$ & $-13.923 \pm 17.047$ \\
\hline $\mathrm{CW} / \mathrm{kg}$ & $309.461 \pm 5.278$ & $313.615 \pm 3.732$ & $309.700 \pm 6.018$ & 0.7587 & $-0.238 \pm 8.005$ & $-8.069 \pm 10.946$ \\
\hline $\mathrm{DP} / \%$ & $57.346 \pm 0.248$ & $57.153 \pm 0.176$ & $56.956 \pm 0.283$ & 0.5862 & $0.389 \pm 0.377$ & $-0.004 \pm 0.516$ \\
\hline $\mathrm{BF} / \mathrm{cm}$ & $0.633 \pm 0.043$ & $0.665 \pm 0.031$ & $0.610 \pm 0.050$ & 0.6113 & $0.023 \pm 0.066$ & $-0.087 \pm 0.091$ \\
\hline $\mathrm{EMA} / \mathrm{cm}^{2}$ & $76.743 \pm 1.312$ & $74.512 \pm 0.927$ & $74.633 \pm 1.495$ & 0.3587 & $2.110 \pm 1.989$ & $2.351 \pm 2.720$ \\
\hline $\mathrm{MS} / 1-7$ & $2.538 \pm 0.194^{\mathrm{a}}$ & $1.910 \pm 0.137^{b}$ & $1.866 \pm 0.222^{\mathrm{b}}$ & $0.0209^{*}$ & $0.671 \pm 0.295^{*}$ & $0.584 \pm 0.404$ \\
\hline
\end{tabular}

LW, live weight; CW, carcass weight; DP, dressing percentage; BF, backfat thickness; EMA, M. Longissimus dorsi area; MS, marbling score

"Effect was significant at $p<0.05$.

${ }^{\mathrm{a}, \mathrm{b}}$ Within a row, means with different superscript letter differ $(p<0.05)$.

\section{Discussion}

Intramuscular fat content, commonly called marbling, refers to the visually discernible deposits of fat within muscle. The intramuscular fat is generally considered to increase juciness and tenderness of meat, and therefore to have a positive association with eating quality (GutierrezGil et al., 2008; Wood et al., 1995). Increased marbling improves the palatability and acceptability of the meat and is an economically important trait of beef cattle in Korea. A better knowledge of the molecular mechanism of marbling is important as it may generate new opportunities for more effective marker assisted selection, leading to economic benefits to the beef industry (Yamada et al., 2009). Recently, the development of genomics has stimulated interest in improving meat quality. DNA markers have been reported in several genes responsible for carcass and meat quality traits in cattle and pigs (Gill et al., 2010; Maj et al., 2006; Otto et al., 2007; Plastow et al., 2005). Genes that regulate metabolism and energy partitioning have the potential to influence economically important traits in farm animals, as do polymorphisms within these genes (Sherman et al., 2008).

The UCP3 is a member of the mitochondrial anion carrier superfamily with high homology (57\%) to UCP1, a well characterized uncoupling protein. Uncoupling protein genes family has five members that named UCP1, UCP2, UCP3, BMCP1, and UCP4 (Vidal-Puig et al., 2000). The tissue distribution of UCP1, UCP2, and UCP3 is markedly different. UCP1 is expressed only in mitochondria of brown adipose tissue where it plays a central role in heat production and thermoregulation by uncoupling respiration from ATP synthesis (Stone et al., 1999). UCP2 is expressed in a variety of tissues, whereas UCP3 is expressed largely in skeletal muscle, white adipose tissue and brown adipose tissue (Fleury et al., 1997; Vidal-
Puig et al., 1997). Thus, UCP2 and UCP3 may have an important roles in determining feed conversion and /or maintenance energy requirements in cattle (Stone et al., 1999). This energy expenditure mechanism can be associated with the metabolism of fat, regulation of body weight and obesity (Fleury et al., 1997; Vidal-Puig et al., 2000; Zhao et al., 2005). Therefore, UCP3 gene has been suggested to play important roles in regulating energy expenditure, body weight and thermoregulation including regulation of fatty acid metabolism. It has also been proposed that UCP3 could prevent the formation of oxygenfree radicals in skeletal muscle (Vidal-Puig et al., 2000).

In this study, we identified ten novel SNPs within the UCP3 gene and the g.3076A $>$ G SNP markers were evaluated with respect to their effects on several carcass and meat quality traits in Korean cattle. A significant difference $(p<0.021)$ was obtained for marbling score between SNP genotypes of g.3076A $>$ G marker but not for other measured traits. The animals with homozygous genotype AA showed a significantly higher marbling score compared with those of heterozygous genotype AG or homozygous genotype GG. The results of this study give strong evidence for the potential for marker assisted selection for meat quality, especially intramuscular fat content. Therefore, the g.3076A $>$ G SNP marker of UCP3 gene can be used for substantial improvement of meat quality traits in Korean cattle. However, this UCP3 SNP marker did not contributed to other traits such as live weight, carcass weight, dressing percentage, backfat thickness, and M. Longissimus dorsi area.

As a first step in assessing the potential role of UCP3 in economically important traits of livestock such as feed conversion and maintenance energy requirements as well as fat metabolism. Stone et al. (1999) first identified five SNPs within the UCP3 gene of cattle: 679 , T/C, intron 2; 820, G/A, exon 3; 1099, G/A, intron 3; 2967, A/C, intron 
5; 3076, A/G, intron 5 (GenBank accession no. AF127030). Among the ten SNPs identified in our study, 3 SNPs (g.1099G $>$ A, g.2966A $>$ C and g.3076A $>$ G) are identical to a previously reported SNPs on this UCP3 gene. However, seven SNPs (UCP3g.2689C $>$ T, UCP3g.2457T $>$ C, UCP3 g.1801Del(T), UCP3g.1796A $>$ G, UCP31794Del (A), UCP3g.1638G $>$ A and UCP3g.1594A $>$ C) detected in this study were recognized as new SNPs identified in Korean cattle. It was found that UCP3 gene was assigned to BTA15, a chromosome previously shown to harbor a locus influencing meat tenderness (Stone et al., 1999). Sherman et al. (2008) reported that g.1099G $>$ A SNP marker, which was previously reported (Stone et al., 1999), showed associations with average daily gain $(p=0.025)$, feed conversion ratio and partial efficiency of growth $(p<0.01)$ in beef cattle, and three SNPs in UCP2 gene showed associations with lean meat yield, yield grade and dry matter intake $(p<0.05)$. These results are consistent with the possible functions of these genes. However, there was no significant association between the g.1099G $>$ A SNP marker and meat quality traits such as carcass marbling score, M. Longissimus dorsi area, backfat thickness and quality grade. Haegeman et al. (2003) selected the UCP2 gene as a bovine candidate gene based on potential effects on carcass and meat traits. On the other hand, Zhao et al. (2002) reported that SNPs in the 3'-UTR region of chicken UCP gene was associated with variation of weight as well as percentage of abdominal fat. In addition, Oh et al. (2006) identified ten SNPs within the UCP gene of the Korean native chicken and showed association of the SNP markers with daily percent lay and mean body weight. Also, SNP markers encompassing the location of UCP2/UCP3 in humans have been associated with resting metabolic rate, body mass, body fatness and fat mass (Sherman et al., 2008). Even though these SNPs in the intron regions of UCP3 gene do not cause amino acid changes, the functions show that UCP gene could be affecting fatness and may be an important candidate gene controlling variation on energy metabolism, growth and body composition traits, especially the fatness traits in domestic animals. In conclusion, SNPs in UCP3 gene were shown to be useful as genetic markers in the selection of Korean cattle with superior meat quality traits. Further studies are necessary to determine the effect of several other SNP markers of $\mathrm{UCP} 3$ gene on carcass and meat quality traits.

\section{Acknowledgement}

This study was supported by Sangji University Research Fund, 2009.

\section{References}

1. Barendse, W., Bunch, J. R., and Harrison, E. B. (2009) Variation at CPE but not CEBPA appears to be associated with intramuscular fat deposition in the longissimus muscle of cattle. Anim. Prod. Sci. 49, 558-562.

2. Boss, O., Samec, P., Giacobino, P. A., Rossier, C., Dullo, A., Seydoux, J., Cuzzin, P., and Giacobino. P. J. (1997) Uncoupling protein-3: A new member of the mitochondrial carrier family with tissue-specific expression. FEBS Lett. 408, 9-42.

3. Fleury, C., Neverov, M., Collins, S., Raimbault, S., Champiqny, O., Levi-Meyrueis, C., Bouillaud, F., Seldin, M. F., Surwit, R. S., Ricquier, D., and Warden, C. H. (1997) Uncoupling protein-2: a novel gene linked to obesity and hyperinsulinemia. Nat. Genet. 15, 269-272.

4. Gill, J. L., Bishop, S. C., McCorquodale, C., Williams, J. L., and Wiener, P. (2010) Associations between single nucleotide polymorphisms in multiple candidate genes and carcass and meat quality traits in a commercial Angus-cross population. Meat Sci. 86, 985-993.

5. Gutierrez-Gil, B., Wiener, P., Nute, G. R., Burton, D., Gill, J. L., Wood, J. D., and Williams, J. L. (2008) Detection of quantitative trait loci for meat quality traits in cattle. Anim. Genet. 39, 51-61.

6. Haegeman, A., Williams, J. L., Law, A., Van Zeveren, A., and Peelman, L. J. (2003) Mapping and SNP analysis of bovine candidate genes for meat and carcass quality. Anim. Genet. 34, 349-353.

7. Katsumata, M., Matsumoto, M., Kawakami, S., and Kaji, Y. (2004) Effect of heat exposure on uncoupling protein-3 mRNA abundane in porcine skeletal muscle. J. Anim. Sci. 82, 3493-3499.

8. Maj, A., Oprzadek, J., Dymnicki, E., and Zwierzchowski, L. (2006) Association of the polymorphism in the 5'-noncoding region of the bovine growth hormone receptor gene with meat production traits in Polish Black-and-White cattle. Meat Sci. 72, 539-544.

9. Matsuda, J., Hosoda, K., Itoh, H., Son, C., Dori, K., Tanaka, T., Fukunaga, Y., Inoue, G., Nishimura, H., Yoshimasa, Y., Yamori, Y., and Nakao, K. (1997) Cloning of rat uncoupling protein-3 and uncoupling protein-2 cDNAs: Their gene expression in rate fedhigh-fat diet. FEBS Lett. 418, 200-204.

10. Miller, S. A., Dykes, D. D., and Polesky, H. F. (1988) A simple salting out procedure or extracting DNA from human nucleated cell. Nucleic Acids Res. 16, 1215.

11. Oh, J. D., Kong, H. S., Lee, J. H., Choi, I. S., Lee, S. J., Lee, S. G., Sang, B. D., Choi, C. H., Cho, B. W., Jeon, G. J., and Lee, H. K. (2006) Identification of novel SNPs with effect on economic traits in uncoupling protein gene of Korean native chicken. Asian-Aust. J. Anim. Sci. 8, 1065-1070. 
12. Otto, G., Roehe, R., Looft, H., Thoelking, L., Knap, P. W., Rothschild, M. F., Plastow, G. S., and Kalm, E. (2007) Associations of DNA markers with meat quality traits in pigs with emphasis on drip loss. Meat Sci. 75, 185-195.

13. Plastow, G. S., Carrion, D., Gil, M., Garcia-Regueiro, J. A., Font I Furnols, M., Gispert, M., Oliver, M. A., Velarde, A., Guardia, M. D., Hortos, M., Rius, M. A., Sarraga, C., Diaz, I., Valero, A., Sosnicki, A., Klont, R., Dornan, S., Wilkinson, J. M., Evans, G., Sargent, C., Davey, G., Connolly, D., Houeix, B., Maltin, C. M., Hayes, H. E., Anandavijayn, V., Foury, A., Geverink, N., Cairns, M., Tilley, R. E., Mormede, P., and Blott, S. C. (2005) Quality pork genes and meat production. Meat Sci. 70, 409-421.

14. Sherman, E. L., Nkrumah, J. D., Murdoch, B. M., Li, C., Wang, Z., Fu, A., and Moore, S. S. (2008) Polymorphisms and haplotypes in the bovine neuropeptide $\mathrm{Y}$, growth hormone receptor, ghrelin, insulin-like growth factor, and uncoupling proteins 2 and 3 genes and their associations with measures of growth, performance, feed efficiency, and carcass merit in beef cattle. J. Anim. Sci. 86, 1-16.

15. Stone, R. T., Rexroad, C. E., and Smith, T. P. L. (1999) Bovine UCP2 and UCP3 map to BTA15. Anim. Genet. 30, 378-381.

16. Van Eenennaam, A. L., Li, J., Thallman, R. M., Quaas, R. L., Dikeman, M. E., Gill, C. A., Franke, D. E., and Thomas, M. G. (2007) Validation of commercial DNA tests for quantitative beef quality traits. J. Anim. Sci. 85, 891-900.

17. Vidal-Puig, A., Solanes, G., Grujic, D., Flier, J. S., and Lowell, B. B. (1997) UCP3: an uncorpling protein homologue expressed preferentially and abundantly in skeletal muscle and brown adipose tissue. Biochem. Biophys. Res. Commun. 235, 79-82.

18. Vidal-Puig, A., Grujic, D., Zhang, C. Y., Hagen, T., Boss, O., Ido, Y., Szczepanik, A., Wade, J., Mootha, V., Cortright, R., Muoio, D. M., and Lowell, B. B. (2000) Energy metabolism in uncorpling protein 3 gene knockout mice. J. Biol. Chem. 275, 16258-16266.

19. Wang, Y. H., Bower, N. I., Reverter, A., Tan, S. H., De Jager, N., Wang, R., McWilliam, S. M., Cafe, L. M., Greenwood, P. L., and Lehnert, S. A. (2009) Gene expression patterns during intramuscular fat development in cattle. J. Anim. Sci. 87, 119-130.

20. Wood, J. D., Nute, G. R., Fursey, G. A. J., and Cuthbertson, A. (1995) The effect of cooking conditions on the eating quality of pork. Meat Sci. 40, 127-135.

21. Yamada, T., Sasaki, S., Sukegawa, S., Miyake, T., Fujita, T., Kose, H., Morita, M., Takahagi, Y., Murakami, H., Morimatsu, F., and Sasaki, Y. (2009) Novel SNP in 5'flankin region of EDG1 associated with marbling in Japanese Black beef cattle. Anim. Sci. J. 80, 486-489.

22. Zhao, J. G., Li, H., Meng, H., Gu, Z. L., Wang, Q. G., and Wang, Y. X. (2002) The study on the uncoupling protein gene as the candidate gene for fatness traits in chicken. $Y i$ Chuan Xue Bao 29, 481-486.

23. Zhao, J. G., Li, H., Wang Y. X., and Meng, H. (2005) The expression characterization of chicken uncoupling protein gene. Asian-Aust. J. Anim. Sci. 18, 1552-1556.

(Received 2011.4.19/Revised 2011.7.5/Accepted 2011.8.3) 